\title{
Managing Successful Overseas Assignments in Malaysia: Social Competencies, Emotional Competencies, Job Performance and Cultural Adjustment
}

\author{
Jugindar Singh Kartar Singh ${ }^{1} \&$ Nik Hasnaa Nik Mahmood ${ }^{2}$ \\ ${ }^{1}$ School of Management, Asia Pacific University of Technology and Innovation, Kuala Lumpur, Malaysia \\ ${ }^{2}$ UTM Razak School of Engineering and Advanced Technology, Universiti Teknologi Malaysia, Kuala Lumpur, \\ Malaysia \\ Correspondence: Jugindar Singh Kartar Singh, School of Management, Asia Pacific University of Technology \\ and Innovation, Kuala Lumpur, Malaysia. E-mail: jugindar.singh@apu.edu.my
}

Received: August 28, 2017

Accepted: September 20, 2017

Online Published: October 18, 2017

doi:10.5539/ijbm.v12n11p174

URL: https://doi.org/10.5539/ijbm.v12n11p174

\begin{abstract}
This study investigates the impact of social and emotional competencies on job performance and the mediating role of cultural adjustment of expatriates engaged in the ICT sector in Malaysia. This was a quantitative research and using a survey method, data was collected from a sample of 301 expatriates. The AMOS software developed for analyzing the Structure Equation Modeling (SEM) was utilized. The findings revealed that social and emotional competencies have a significant impact towards job performance. The findings also supported the role of cultural adjustment as a mediator between competencies and job performance. The findings supported the results from some earlier studies and also bring out several new ideas such as the importance of competencies and cultural adjustment. The findings have significantly contributed to the advancement of knowledge in job performance and cultural adjustment and it is evident that expatriate social and emotional competencies facilitate job performance and cultural adjustment. The implications were in the areas of expatriate selection, training and support practices. It is recommended that organizations consider both social and emotional competencies and implement suitable HR policies to select the right candidate. The results of this study will add to the current body of knowledge as well as assist in creating foundational solutions to ensure success in expatriate global assignments in Malaysia.
\end{abstract}

Keywords: cultural adjustment, performance, expatriate and competencies self-motivation

\section{Introduction}

\subsection{Background}

Having the right people on the ground is essential for organizations that are pursuing growth in new markets in today's globalized environment (KPMG, 2016). For MNCs, attracting new talent in chosen markets is vital to achieve growth (KPMG, 2016). MNCs are increasingly looking to enhance their mobility policies to attract and retain key global talent (KPMG, 2012). As argued by Palthe (2004), MNCs depend on expatriates for growth and competitive advantage. This effort requires selection of globally competent people. Therefore, having the right people to manage MNCs is a critical success factor in international operations (Dowling, Festing \& Engle, 2008). However, many companies find deploying and developing talent in emerging markets to be a major challenge (Dewhurst, Harris \& Heywood, 2012).This has spurred MNCs which face labor shortages to fill the gap by recruiting expatriates from other countries (Liu \& Lee, 2006). The number of expatriates sent by organizations to foreign countries is also ever increasing steadily. A survey by Brookfield GRS (2012) reported that $64 \%$ of respondents indicated that their international assignee population had increased.

Malaysia aspires to be a high income nation and to emerge as a global talent hub by 2020 (MyStarjob.com, 2014). Winning in the international arena requires top notch talent and the Malaysian Government recognizes the contribution of eminent foreign talent (MyStarjob.com, 2014). Information and Communications Technology (ICT) industry has become an important sector in Malaysia. The ICT industry in Malaysia shows resilience and continues its growth path (Steven, 2016). The share of the ICT industry to the economy expanded from $16.5 \%$ in 2010 to $17.6 \%$ in 2015 (MSC Malaysia, 2015). The year 2015 witnessed a 7.4\% increase in jobs with an addition 
of 10,981 new jobs. Non-Malaysian knowledge workers made up 13.6\% of the total workforce in the ICT sector in 2015. However, the availability of innovative local talents for research and innovation activities remains a major challenge. This problem is addressed by importing foreign talents (PIKOM, 2012). Therefore, the expatriate population in the ICT sector in Malaysia is worth studying because this sector is one of the national key economic sectors promoted by the Malaysian government as part of its growth strategy (Immigration in Malaysia, 2013).

\subsection{Problem Identification}

For business development purposes, employees enriched with internation experience are expected to bring deeper insights and skill sets as well as demonstrate exceptional value (KPMG, 2016). However in reality, 65 percent of participants in a survey carried out by KPMG did not have a provision in place to make an informed assessment of assignee suitability (KPMG, 2016). Therefore, MNCs are now said to face the risk of failure and the related cost of failure (Perkins, 2006). Direct costs of expatriation may be as high as three times the domestic salary (Dowling et al., 2008). Companies had reported that $6 \%$ of international assignments had failed (Broofield GRS, 2012). Tung (1982) found that more than half of the companies in USA had failure rates of $10 \%-20 \%$. Based on a survey by KPMG (2012), 55\% of the respondents stated that up to $5 \%$ of assignees were recalled from the host country or dismissed because of inability to perform their jobs effectively.

Due to the growth and importance of global assignees, research on expatriate cultural adjustment and performance has received considerable attention (e.g., Aykan, 2014; Selmer, 2002). Past research has revealed that expatriate job performance plays an important role (e.g., Cote \& Miners, 2006). Expatriate cultural adjustment has received attention because expatriates may face cultural challenges while working for MNCs (Peltokorpi \& Clausen, 2011). To improve performance and cultural adjustment, researchers attest to the importance of several individual factors and competencies (e.g., Bhatti et al., 2013). Past research has shown a positive relationship between emotional competencies and job performance (Gabel et al., 2005). Social competencies were also identified as predictors of job performance and adjustment by several researchers (e.g., Templer, 2010). However, the relationship between competencies, cultural adjustment and job performance of expatriates has not been empirically tested in Malaysia. This study intends to integrate social and emotional competencies aspect of antecedents to identify their influences on expatriate adjustment and performance. A clear understanding would aid decision makers and human resource professionals in the design of appropriate expatriates' selection mechanism and training programs.

\section{Literature Review}

\subsection{Job Performance}

Many authors have defined performance and the related parameters (e.g., Campbell, 1990). Researchers have paid attention to the predictors of performance (e.g., Leea and Donahue, 2012). Campbell (1990) coming from the psychological perspective, described performance as behavior. This definition thus differentiates performance from outcomes. There are several other factors that determine outcomes besides an employee's behavior and actions (Campbell, 1990). Campbell (1990) asserted that performance is also multidimensional and proposed an eight factor model of performance. This view is shared by many other researchers (e.g., Borman \& Motowidlo, 1997). Leea and Donohue (2012) tested the model developed by Campbell (1990) and further amended the model of performance with six components. Borman and Motowidlo (1997) divided job performance into task and contextual performance. As stated by Viswesvaran, (1993), there are very few efforts directed towards the development of generizable models of performance. It can be assumed that what constitutes performance differs amongst jobs. As a result, there are a high number of measures as indicators of job performance.

Several attempts were made by researchers to identify the dimensions that contributed to effective performance by expatriates. Past literature indicated that individual differences such as stress tolerance, personality and self-efficacy are related to job performance by expatriates (e.g., Holopainen \& Björkman, 2005; Bhatti et al., 2013). However, as stated by Arthur and Bennet (1997), these initiatives have been somewhat informal and have not been formulated into any formal theoretical models. One of the meaningful contributions was by Arthur and Bennet (1995). Arthur and Bennet (1995) identified five factors namely job knowledge, family situation, relational skills, flexibility/adaptability and extra-cultural openness. A study by Caligiuri (1997) identified the personality characteristics of extroversion, emotional stability, agreeableness, and conscientiousness as predictors of job performance. Several different expatriate job performance dimensions had been identified by several researchers. The lack of exact understanding as to what factors relate to expatriates job performance indicates a paucity of research (Arthur \& Bennet., 1997). For this research, the job performance dimensions are 
based on past research by Caligiuri, (1997). The performance dimensions are differentiated between the contextual variables that are prosocial and the contextual variables that are managerial (Caligiuri, 1997).

\subsection{Cultural Adjustment}

Based on past research, there are different definitions of cultural adjustment. Palthe (2004) defined cross-cultural adjustment as the process of living and working in a foreign country. According to Black (1988), cultural adjustment refers to psychological discomfort that is categorized as interaction, work, and general adjustment. Aycan (1997) argued that cultural adjustment is conceptualized as the degree of fit between the expatriate manager and the new environment in both work and non-work domains. Selmer (2002) defined cultural adjustment as characteristics for achieving effectiveness in interpersonal exchange with host country nationals. Hofstede (1980) stated that adjustment is "the forced exposure to alien cultural environment that can put people under heavy stress". Most definitions of cultural adjustment refer to adaptation in another host country culture. In this research, cultural adjustment can generally be defined as the process of adjustment to working and living in a foreign country.

All expatriates crossing cultures may face some challenges as they pioneer lives of uprootedness (Kim, 2001). Ryan (2000) argued that expatriates will become distressed if they are unsuccessful in mastering new skills. Matsumoto et al. (2004) stated that culturally adjusted expatriates demonstrate self-esteem, self-confidence, positive mood and stress reduction. On the contrary, maladjusted assignees have difficulty adapting to the host country's norms and behaviors (Bhaskar et al., 2005). Several past empirical studies have tried to identify the factors that have a positive influence on cultural adjustment (Lee \& Kartika, 2014). Past international experience (Bhaskar et al., 2005), and awareness of cross cultural communication (Harris et al., 2004) have been examined as antecedents of an expatriate's cultural adjustment. Despite the contributions of previous studies, there are still some areas of research that need to be explored to understand the dynamics of an expatriate's cultural adjustment which is essential in allowing expatriates to optimize their experience while working in other countries (Mercer, 2013). As stated in the HSBC Expat Explorer Survey (2012), Malaysia is still a difficult place for expatriates to adjust and integrate. Therefore, cultural adjustment is a critical skill for expatriates and past research has identified several predictors of such cultural adjustment.

\subsection{Social Competencies}

Researchers have described various skills under the social competencies cluster (e.g., Jordan \& Cartwright, 1998; Goleman, 1998). Social competence refers to personal, interpersonal and intercultural competence and all forms of behaviors that equip individuals to participate in an effective and constructive way with their social and working life (EU Report, 2006). Social competencies encompass the behavior that an individual needs to possess and needs to demonstrate in his or her cooperation and interactions with others to build relationships (Sinnott, Madison and Pataki, 2002). Baron and Markman (2003) included four distinct aspects of social competencies. They are social perception, social adaptability, impression management and expressiveness. Similarly, Goleman (1998) included influence, communication, conflict management, change catalyst, building bonds, collaboration, and team capabilities in the social skills cluster. As a result, there are a high number of measures as indicators of social competencies.

Several attempts were made by researchers to identify the social competencies that contribute to success of expatriates (e.g.; Jordan et al., 1998; Jokinen, 2005). Jordan et al. (1998) described social competence to encompass moderate extroversion, listening skills, ability to interact, managing first impressions, and multicultural communicative competence. According to Arthur and Bennet, (1995), social skills also consist of relational skills and the display of respect, courtesy, kindness, empathy, non-judgmentalness, integrity and confidence. Black et al. (1991) included relational skills as a criterion for in-country adjustment of expatriates. Peltokorpi, (2008) included local language proficiency that helps expatriates learn appropriate work values. Jokinen (2005) stated that competencies include relational skills, linguistic ability and cultural sensitivity.

\subsection{Emotional competencies}

Emotional competence resonates with different perspectives of EI or Emotional Intelligence (e.g., Mayer \& Salovey, 1997; Goleman, 1998). The ability based model by Salovey and Mayer (1990) defined EI as "intelligence" which is, a set of mental abilities dealing with emotions and the processing of emotional information. . Goleman (1998) defined an "emotional competence" as a "learned capability based on emotional intelligence which results in outstanding performance at work." Unlike the ability based model by Mayer and Salovey (1997) which proposes that individuals vary in their ability to process information of an emotional nature, Goleman (1998) focuses on EI as a wide array of competencies and skills which drive job performance. Bar-On (2006) defined EI as a cross-section of interrelated social and emotional competencies and skills that 
influence intelligent behavior. Stein and Book (2011) argued that EI is a set of emotional and social skills that influence the way we perceive and express ourselves, develop and maintain social relationships and cope with challenges. With several definitions of EI in play, there is now an ongoing debate about Emotional Intelligence.

Goleman (1998) argued that EI is more important than IQ. In a survey, cognitive ability contributed around 20\% toward success while the remaining $80 \%$ was directly attributable to EI. Goleman (1998) further asserted that EI increases productivity and performance in an occupational setting. Momm et al., (2015) found that emotional abilities enable people to be more successful at work. Several other researchers tested and found evidence to support EI as a determinant of job performance (e.g., Quebberman \& Rozell, 2002). However, there has been a general lack of systematic analysis substantiating this claim (Mishra \& Mohapatra, 2010). Zeidner, Matthews and Roberts (2004) stated that EQ is the potential one has at learning certain emotional responses but EQ does not ensure that people will definitely manifest competent behaviors on their jobs. Petrides and Furnham (2000) argued that EI is merely a moral quality and not a form of intelligence. Locke (2005) also argued that EI was defined so broadly that it had no intelligible meaning. Locke (2005) supported the critical role played by cognitive intelligence and rational thinking. Ashkansy and Daus (2002) stated that EI is distinct from, but positively related to other intelligences. Thus, the past studies show negative, positive and mixed results.

\subsection{Relationship between Social Competencies and Job Performance}

Social competencies have been identified by researchers as one of the critical personal qualities that are linked with adjustment and job performance of expatriates (e.g., Furusawa and Brewster, 2016; Hochwarter, Will, Treadway, \& Ferris, 2006). A study by Witt and Ferris (2003) linked social skills with job performance. Hochwarter et al. (2006) argued that social competencies lead to increased interactions with host country nationals. The more expatriates interacts with host nationals, the more they will receive information and as a consequence, the expatriate will be able to perform better in the new environment (Lee \& Sokoco, 2010). Consequently, higher levels of adjustment are related to improved task execution (Bhaskar et al., 2005).

Under social competencies, researchers have placed high importance on relational abilities (e.g., Furusawa and Brewster, 2016). Furusawa and Brewster (2016) found that relational abilities were associated with job performance. Solomon et al., (2009) further stressed that the relationship dimension is the foundation of all interpersonal interactions. Jordan and Cartwright (1998) also outlined relational ability as one of the criteria that contributed to performance and adjustment of expatriates. On the contrary, a study by Holopainen and Bjo"rkman (2005), found that relational ability was not significantly related to success. Communication ability and language ability has also been widely studied (e.g., Furusawa and Brewster, 2016). Holopainen and Bjo"rkman (2005) stressed the importance of communication ability for expatriate success. Furusawa and Brewster (2016) found that language ability was positively related to work adjustment. Researchers generally agreed on the importance of such communication ability but some disagreement exists among researchers on linguistic ability. According to some other researchers, linguistic ability is a competence that can be critical for success of expatriates (e.g., Peltokorpi, 2008; Guadalupe, 2006). Guadalupe (2006) concluded that language proficiency is an important factor to enable the person to adjust in the foreign country. On the contrary, other researchers have pointed out that language skills may be regarded as of critical importance for some expatriate positions, but lesser in others (Dowling et al., 2008). Based on the research findings discussed above and logically extending them, it can be concluded that social competencies are a valid predictor of job performance.

H1: Social competencies have significant effect on job performance of expatriates

\subsection{Relationship between Emotional Competencies and Job Performance}

The relationship between EI and performance has received much attention by researchers (Mishra \& Mohapatra, 2010). Boyatzis (2009) claimed that an EI competency is an ability to recognize, understand, and use emotional information about oneself that leads to or causes effective or superior performance. Parke, Seo, and Sherf (2015) found that emotion regulation ability enables employees to maintain higher positive effect. A research by Stein and Book (2011) revealed that the correlation between EI and performance in a variety of careers has ranged up to .45 attributable to EI with an average of .30. Aykan (2014) found positive relationships between the EI and contextual performance of employees. Gabel et al. (2005) stated that although technical competencies are important, EI that covers the capacities of empathy, and social relations which predict better success. Other researchers have also argued that EI is an important predictor of performance (Araujo \& Taylor, 2012). However, a number of different viewpoints have emerged about what EI actually is (Neale et al., 2009).

Studies have shown that expatriates with high EQ tend to perform well in global workplace (Cote \& Miners, 2006). O'Boyle, et al., (2011) argued that there is good reason to believe that EI predicts job performance because it is likely that the ability to recognize emotions in one's self and in others contributes to effective social 
interaction, as does the ability to regulate one's own emotions. Emotionally intelligent expatriates are able to regulate their own emotions and the emotions of others and use emotional information in decision making to achieve positive performance outcomes (Ashkanasky \& Daus, 2002). People with high EI are also more likely to perceive context-driven emotion patterns and are therefore better able to adapt to these situations (Lillis \& Tian, 2009). Similarly, Cherniss (2000) pointed out that a person's ability to perceive, identify, and manage emotions provides the basis for the kinds of emotional competencies that are important determinants of success in any job. However, a study by Cote and Miners (2006) revealed that while EI was a predictor of job performance, it did not have a linear effect. Cote and Miners (2006) found that as cognitive intelligence increases, EI becomes a stronger predictor of task performance. However, the growing body of research on EI provides support for the notion of the relationship to performance. Goleman (1998) argued that, in addition to intellectual or technical skills, competencies based on EI plays a strong role in performance. Based on the above, it it is posited that:

H2: Emotional competencies have significant effect on job performance of expatriates.

\subsection{Mediating Role of Cultural Adjustment}

Past literature has identified a number of predictors or antecedents that are associated with cultural adjustment such as self-efficacy and adaptability (Bhatti et al., 2013). The relationship between job performance and cultural adjustment has been studied by several researchers (e.g., Shi \& Franklin, 2014). Wang and Tran (2012) found that an expatriate's interaction and work adjustment have significant impacts on job performance. Expatriates who are well adjusted will have more time and emotional investment available to adjust their behaviors that facilitate their job performance (Haslberger, 2008). Takeuchi et al. (2005) stressed that expatriates' work adjustment is correlated with their job performance. Kraimer et al. (2001) provided initial evidence that expatriates who were well adjusted at work and who were comfortable interacting with host-country citizens were perceived to be higher performers. Maladjustment could be translated into stress and poor performance (Koteswari \& Bhattacharya, 2007). Stress coming from work and non-work domains had tendencies of inducing fatigue which resulted in maladjustment and poor performance (Bhaskar et al., 2005). Caligiuri (2012) further argued that performance depended on not only the content of jobs but also on the expatriates' ability to function in the cross-cultural context of their jobs.

Higher EI was reported to contribute to better cultural adjustment and performance (Lee \& Kartika, 2014; Gullekson \& Tucker, 2012). The results of this study by Lee and Kartika (2014) illustrated that expatriates with higher EI and cultural intelligence can adjust more easily in the new work environment. Koveshnikov et al. (2014) found a significant relationship between EI and expatriates' cultural adjustment. An expatriate with higher EI was documented to have better emotional control (Lii \& Wong, 2008). Wong, Law, \& Wong, (2004) found that expatriates with higher EQ had tendencies to have higher ability to understand their emotions and thereafter adjust in the new environment. Expatriates with greater emotional resilience competency possessed the psychological hardiness that allowed them to carry on through difficult challenges (Mendenhall et al., 2008). EI had also been established as a predictor of intercultural growth via changes in intercultural communication apprehension and international awareness (Gullekson \& Tucker, 2012). Hence, it is more likely that expatriates who are high in EI are selected as they are more likely to perceive context-driven emotion patterns and are therefore better able to adapt to these situations (Lillis \& Tian, 2009). These findings emphasized the importance that was placed on emotional competencies of expatriates.

Past research has shown that expatriates with good social network and social capital were effective in terms of adjustment and performance (Lee \& Kartika, 2014; Malek, Jaguli, \& Palil, 2012). Lee and Kartika (2014) found that social capital could enhance the success of expatriate adjustment which could further influence expatriate performance. Past research had shown that social interaction and relationships during global assignments were one of the critical predictors of cultural adjustment (Lee, 2005; Aycan, 1997; Caligiuri \& Lazarova, 2002). The involvement of expatriates in social activities in the host country rather than only work related activities enhanced their abilities to adjust effectively (Liu \& Lee, 2008). Caligiuri and Lazarova (2002) argued that social interactions from all sources could provide expatriates with the emotional support that could help them overcome the negative feelings and experiences that are a natural part of the cross-cultural transition. Social network may positively influence expatriate cultural adjustment and this could further influence job performance (Bhatti et al., 2013). Hence, socialization may be considered a strong predictor of cross-cultural adjustment (Palthe, 2004). Expatriates who better socialized at the host country abroad were likely to adjust more effectively (Lee, 2005).

The role of cultural adjustment as a mediator between social competencies and job performance has not been widely studied in Malaysia. The following hypothesis was formulated for testing in the present study.

H3a: Cultural adjustment mediates the relationship between social competencies and job performance 
H3b: Cultural adjustment mediates the relationship between emotional competencies and job performance

\section{Method}

\subsection{Identify Subsections}

This research is based on positivism philosophy. (Saunders, Lewis, \& Thornhill, 2012). With a deduction approach, a theory and hypotheses were developed. A quantitative research strategy using the survey method was designed to collect cross sectional data and test the hypotheses. This was a cross sectional research to collect primary data using a self-administered questionnaire. The self-administered questionnaires were administered electronically using the internet or delivered by hand (Saunders et al., 2012).

\subsection{Sampling and Sample Size}

The target population was expatriates working in the ICT sector. With simple random sampling technique, a sampling frame of 1,130 respondents was prepared. Based on the estimated return rate of 30\%, 900 target respondents were randomly selected. Sample size was based on formula by Krejcie and Morgan (1970). The confidence level was $95 \%$ and the degree of accuracy was .05 . There are 119,138 jobs in the ICT sector in Malaysia and 13\% of these jobs are held by non-Malaysians (MSC Malaysia, 2015). In the ICT sector, highly skilled workers accounted for 82 percent of the total employment (Immigration in Malaysia, 2013). Based on the population of 12000 expatriates, the sample size based on the formula by Krejcie and Morgan (1970) was 373.

\subsection{Instrumentation}

Self-administered questionnaires were used to collect data (Saunders, et al., 2012). Demographic variables (gender, marital status and age) were included. Fixed alternative questions required the respondents to choose the best answer based on a five-point Likert-type scale. The questionnaires encompass items measuring job performance, emotional competencies, job related competencies and cultural adjustment.

\subsection{Data Collection}

Email response rates may only approximate $25 \%$ to $30 \%$ without follow-up (Sheehan, 2001). Initially a total of 846 mails were sent through e-mail. A multimode approach to e-mail survey administration can enhance response rates (Sheehan, 2001). The direct distribute and collect method was used for respondents that could be reached personally. Follow up through e-mail was done after one month. At the end of the third month, the response rate was 25 percent ( 225 respondents). The data collection was extended by another month and further attempts were made to make direct appointments. Finally, 318 questionnaires were completed.

\subsection{Data Analyses}

The AMOS software developed for analyzing the Structure Equation Modeling (SEM) and SPSS were used to test the goodness of fit and present the model in a causal path diagram to show the hypothesized relationships among constructs of interest. Confirmatory Factor Analysis (CFA) which employs a set of measures to achieve the model fit was utilized (Hair et al., 2006). The CFA method was chosen because of its ability to assess the validity, unidimensionality, and reliability of a latent construct (Hair et al., 2006). SEM is an efficient method to perform CFA for measurement models, analyze the causal relationships in a structural model, and test the hypotheses for mediators (Awang, 2012). Using Amos Graphic interface, the structural model was created to test causal effects and the mediation effects. The two sets of text output namely the standardized regression weights and the regression weights were examined.

\section{Results}

\subsection{Demographic Profiles of the Respondents}

The respondents included $71 \%(n=214)$ male $29 \%(n=87)$ female. Majority of the respondents, $57 \%(n=172)$ were married. The respondents age included $41 \%(n=123)$ between the age range of 26 to 30 years, $29 \%(n=87)$ between the age range of 31 to 35 years and 3\% $(n=9)$ above the age of 45 years. Majority of the respondents, $34 \%$ $(\mathrm{n}=102)$ stayed for more than 3 years. The participants are come from various countries with majority $59(19.6 \%)$ were from India, $47(15.6 \%)$ from Europe, 51 (16.9\%) from ASEAN countries, $29(9.7 \%)$ and the rest from other countries.

\subsection{Descriptive Statistics}

Based on Table 1, the values of skewness and kurtosis values are within +3 and -3 standard deviations from its mean The mean of all the variables is above 4 and the standard deviation is low (Zikmund et al., 2010). 
Table 1. Descriptive statistics

\begin{tabular}{llllll}
\hline & Mean & Std. Deviation & Variance & Skewness & Kurtosis \\
\hline Performance & 4.1971 & .45171 & .204 & -.370 & -.212 \\
Social Competencies & 4.0902 & .47596 & .227 & -.006 & -.545 \\
Emotional Competencies & 4.1100 & .49065 & .241 & -.282 & .453 \\
Cultural Adjustment & 4.1845 & .55170 & .304 & -.374 & -.003 \\
\hline
\end{tabular}

\subsection{Reliability}

The Cronbach alpha coefficient for the dependent variable was 0.919 and 0.924 and 0.9080 for social and emotional competencies respectively. The Cronbach alpha value was above 0.7 and this is acceptable (Pallant, 2010). Pilot testing was done and this provided with some idea of the questionnaire's face validity (Saunders et al., 2012). For face validity, experts were asked to comment on the representativeness and suitability of the questions (Saunders et al., 2012).

\subsection{Analysing and Evaluating the Fitness of the Measurement Model}

In SEM, the Fitness Indexes reflect how fit is the model to the data (Hair et al., 2006). There are three model fit categories namely Absolute Fit, Incremental Fit, and Parsimonious Fit (Awang, 2012). Hair et al. (2006) recommend the use of at least one fitness index from each category of model fit. The measures include Root Mean Square Error of Approximation (RMSEA), Tucker Lewis Index (TLI), Comparative Fit Index (CFI) and Chi Square/Degrees of Freedom. The results shown in Table 2 indicates that the model adequately fits the data and the indices indicates a good fit to the model $(\mathrm{CFI}=.906, \mathrm{TLI}=.900, \mathrm{RMSEA}=.050)$. A RMSEA value of 0.05 indicates that only the model has not explained $5 \%$ of the variance in the data (Awang, 2012)

Table 2. Categories of model fit, level of acceptance and Index Values

\begin{tabular}{|c|c|c|c|c|c|c|}
\hline \multicolumn{2}{|c|}{ Name of Category } & \multirow{2}{*}{$\begin{array}{l}\text { Name of Index } \\
\text { RMSEA }\end{array}$} & \multirow{2}{*}{$\begin{array}{l}\text { Level of Acceptance } \\
\text { RMSEA }<0.08\end{array}$} & \multirow{2}{*}{$\begin{array}{l}\text { Actual } \\
\text { Value } \\
.050\end{array}$} & \multirow{2}{*}{ Index } & \multirow{2}{*}{$\begin{array}{l}\text { Accepted } \\
\text { Level achieved }\end{array}$} \\
\hline 1. & Absolute Fit & & & & & \\
\hline \multirow{3}{*}{2.} & \multirow{3}{*}{ Incremental Fit } & GFI & $\mathrm{GFI}>0.09$ & .0887 & & Level achieved \\
\hline & & CFI & $\mathrm{CFI}>0.09$ & .906 & & Level achieved \\
\hline & & TLI & $\mathrm{TLI}>0.09$ & .900 & & Level achieved \\
\hline 3. & Parsimonious Fit & Chi-Square/ df & Chi-Square/ df $<3.0$ & 1.752 & & Level achieved \\
\hline
\end{tabular}

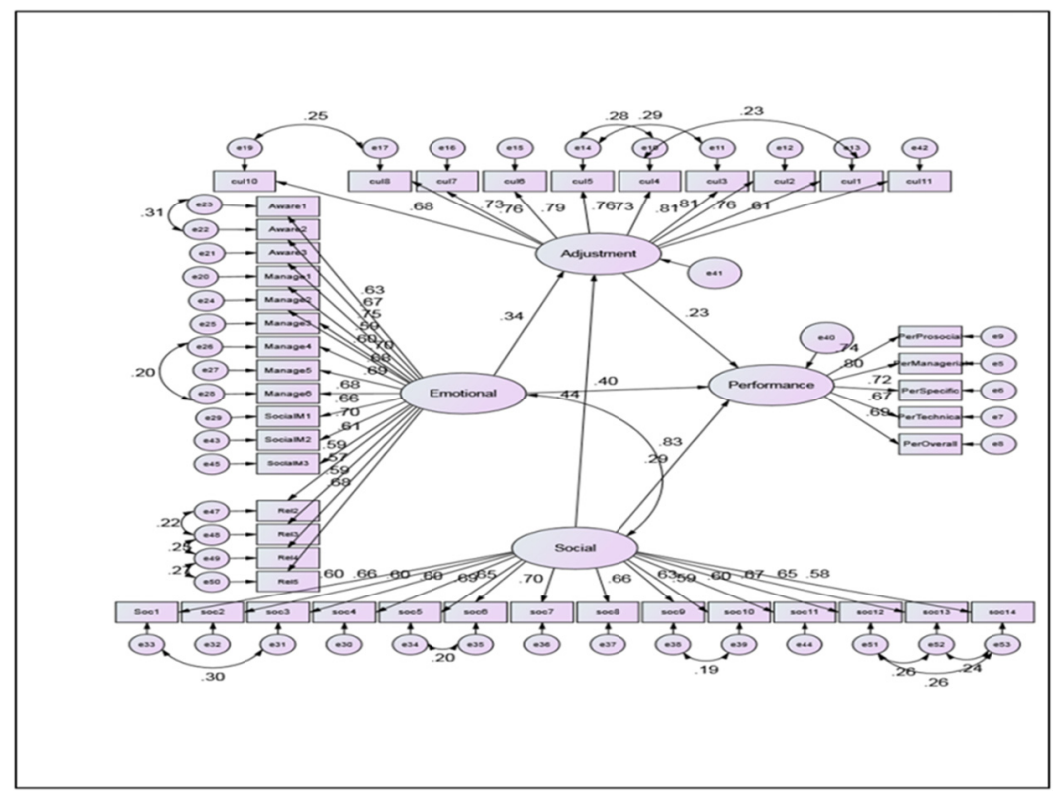

Figure 1. The structural model 
The factor loading for each item in a measurement model to measure the latent constructs are shown in Figure 1 below. The entire items are having a factor loading of at least 0.6 and as such the fitness indexes for that measurement model are achieved. Two constructs with Factor loading less than 0.6 were deleted (Awang, 2012).

In Table 3, the regression weights indicate the estimate of beta coefficient which measures the effects of every exogenous construct on the endogenous construct. The path coefficient of Social Competencies to Performance is 0.288 and the effect is significant $(\mathrm{p}<0.05)$. Thus, the hypothesis H1 is supported. The path coefficient of Emotional Competencies to Performance is 0.395 and the effect is significant $(\mathrm{p}<0.05)$. Thus, the hypothesis $\mathrm{H} 2$ is supported.

Table 3. Path Regression Coefficient: Emotional Competencies

\begin{tabular}{llllll}
\hline & & & Estimate & P & Result \\
\hline Performance & $<---$ & Emotional Competencies & .395 & $* * *$ & Significant \\
Adjustment & $<---$ & Emotional Competencies & .340 & $* * *$ & Significant \\
Performance e & $<---$ & Social Competencies & .288 & $* * *$ & Significant \\
Adjustment & $<---$ & Social Competencies & .443 & $* * *$ & Significant \\
Performance & $<---$ & Adjustment & .229 & $* * *$ & Significant \\
\hline
\end{tabular}

When analyzing the mediator, there are two effects involved namely direct effect and indirect effect (Hair et al., 2006). Firstly, the direct effect of IV on DV was tested. The output in Table 3 shows the results. The mediator variable was entered to test the effect as shown in Table 3. When the mediating variable $\mathrm{M}$ enters the model, the value of path coefficient for IV is expected to reduce (Awang, 2012).

For Social competencies, both indirect paths are significant. The effect was still significant after the mediator enters the model. For Emotional competencies, both indirect paths are also significant. The effect was still significant after the mediator enters the model. If it is reduced but still significant, the mediation effect here is called "partial mediation" (Awang, 2012). Thus, Hypothesis H3a and H3b were supported.

\section{Discussion and Conclusion}

The results of this study revealed that emotional competencies have the most influence on performance of expatriates followed by social competencies. The findings emphasize the criticality of competencies, expatriate performance and cultural adjustment in the ICTs sector in Malaysia. The evidence from this study suggests that the greater the competencies, the greater will be the job performance of expatriates. The findings of this study concur with past research that found evidence to support emotional competencies (Aykan, 2014; Gabel et al., 2005). Past research also showed that social competencies have a predictive effect on job performance (Furusawa and Brewster, 2016). The results of this study further support the notion that competencies play a positive role in the cultural adjustment of expatriates in the ICTs sector in Malaysia. Therefore, cultural understanding and competencies development should be built into all global expatriate deployment systems. Cultural adjustment to different environments can improve the overseas experience and productivity (Harris et al., 2004). It is likely that performance is affected if the expatriate is not adjusted to living and working in Malaysia (Selmer, 2002).

The findings will also provide theoretical and practical implications for managing expatriates and offer an alternative viewpoint. This research helps to fill the research gaps, hence adds to the literature of expatriates performance and adjustment. The evidence from this study contains implications for companies in selecting, training, motivating and providing support to expatriates. Hence, human resource managers should consider competencies and cultural adjustment before engaging expatriates. Knowledge of Malaysian culture is necessary and training should be tailored based on Malaysian culture. A successful assignment starts with an appropriate selection and training of expatriates and the attributes highlighted in this study should become the key selection criteria and arristhe content and design of the training plan. The findings are also expected to assist in creating foundational solutions to support successful performance by expatriates engaged by organizations operating in the ICT sector in Malaysia.

This study has some limitations that also paved several directions for future research. There are other moderators and mediators such as training that should be examined in future studies. The data for this study was collected via a self-reported questionnaire that could be susceptible to bias. Expatriates who failed in their assignment or expatriates who returned pre-maturely to their home country were not included. These limitations of this study 
provide directions for future research. For future studies, a more in-depth research on factors that affect performance and cross cultural adjustment of expatriates can be undertaken. Similar studies in other sectors can yield further evidence and different findings. In addition, future research can include the mediating impact of organizational support strategies. It is also recommended that future research should include assessment from various sources that include family and peers.

\section{References}

Araujo, S. V. A., \& Taylor, S. N. (2012). The influence of emotional and social competencies on performance of Peruvian refinery staff. Cross Cultural Management, 19(1), 19-29. https://doi.org/10.1108/13527601211195600

Arthur, W., \& Bennett, W. (1995). The international assignee: The relative importance of factors perceived to contribute to success. Personnel Psychology, 48(1), 99-114. https://doi.org/10.1016/j.sbspro.2011.10.412

Arthur, W., \& Bennett, W. (1997). A comparative test of alternative models of international assignee job performance. In D. M. Saunders (Ed.), New approaches to employee management, Vol. 4: Expatriate management: Theory and research (pp. 141-172). Stamford, CT: JAI Press.

Ashkanasy, N.M. \& Daus, C.S. (2002). Emotion in the workplace: the new challenge for Managers. Academy of Management Executive, 16(1), 76-86. https://doi.org/10.2307/4093839

Awang, Z., (2012). Research Methodology and Data Analysis. Penerbit Universiti Teknologi MARA, Shah Alam.

Aycan, Z. (1997). Expatriate adjustment as a multifaceted phenomenon: Individual and organizational level predictors. The International Journal of Human Resource Management, 8(4), 434-456. https://doi.org/10.1080/095851997341540

Aykan, E. (2014). Relationship between emotional competence and task contextual performance of employees. Problems of Management in the 21st Century, 9(1), 8-16.

Bar-On, R. (2006). The Bar-On Model of Emotional-Social Intelligence (ESI). Retrieved March 20, 2015 from http://www.eiconsortium.org/pdf/baron_model

Baron, R. A., \& Markman, G. D. (2003). Beyond social capital: The role of entrepreneurs' social competence in their financial success. Journal of Business Venturing, 18(1), 41-60. https://doi.org/10.1016/S0883-9026(00)00069-0

Bhaskar-Shrinivas, P., Harrison, D.A., Shaffer, M. A., \& Luk, D. M. (2005). Input-based and time-based models of international adjustment: meta-analytic evidence and theoretical extensions. Academy of Management Journal, 48(2), 257-281. https://doi.org/10.5465/AMJ.2005.16928400

Bhatti, M. A., Battour, M. M., \& Ismail, A. R. (2013). Expatriates adjustment and job performance. An examination of individual and organizational factors. International Journal of Productivity and Performance Management, 62(7), 694-717. https://doi.org/10.1108/EDI-01-2013-0001

Black, J. S. (1988). Work role transitions: A study of American expatriate managers in Japan. Journal of International Business Studies, 19(2), 277-294. https://doi.org/10.1057/palgrave.jib

Borman, W., \& Motowidlo, S. (1997). Task performance and contextual performance: The meaning for personnel selection research. Human Performance, 10(2), 99-109. https://doi.org/10.1207/s15327043hup1002_3

Boyatzis, R. E. (2009). Competencies as a behavioral approach to emotional intelligence. Journal of Management Development, 28(9), 749-70. https://doi.org/10.1108/02621710910987647

Brookfield GRS. (2012). Global Relocation Trends 2012 Survey, Brookfield Global Relocation Services LLC.

Caligiuri, P. M. (1997). Assessing expatriate success: Beyond just being there. New Approaches to Employee Management, 4, 117-140.

Caligiuri, P. M. (2012). Cultural Agility: Building a Pipeline of Successful Global Professionals. San Francisco: Jossey-Bass.

Caligiuri, P. M., \& Lazarova, M. (2002). A model for the influence of social interaction and social support on female expatriates' cross-cultural adjustment. International Journal of Human Resource Management, 13(5i, 761-772. https://doi.org/10.1177/001872679104400505

Campbell, J. P. (1990). Modeling the performance prediction problem in industrial and organizational 
psychology. In M. D. Dunnette and L. M. Hough (Eds.), Handbook of Industrial and Organizational Psychology (pp. 687-732). Palo Alto, CA: Consulting Psychologists Press.

Cherniss, C. (2000). Emotional intelligence: What it is and why it matters. Proceedings of Annual Meeting of the Society for Industrial and Organizational Psychology. Retrieved January 12, 2015 from http://www.wghill.com/assessments/what_is_emotional_intelligence.pdf

Cote, S., \& Miners, C. T. (2006). Emotional Intelligence, Cognitive Intelligence, and Job Performance. Administrative Science Quarterly, 51(1), 1-28. https://doi.org/10.2189/asqu.51.1.1

Dewhurst, M., Harris, J., \& Heywood, S. (2012). The global company challenge. McKinsey Quarterly, 3, 76-80.

Dowling, P. J., Festing, M., \& Engle, A. D. (2008). International Human Resource Mgmt. London: Cengage.

Furusawa, M., \& Brewster, C. (2016). IHRM and expatriation in Japanese MNCs: HRM practices and their impact on adjustment and performance. Asia Pacific Journal of Human Resources, 54(4), 396-420. https://doi.org/10.1111/1744-7941.12106

Gabel, R. S., Dolan, S. L., \& Cerdin, J. L. (2005). Emotional intelligence as predictor of cultural adjustment for success in global assignments. Career Development International, 10(5), 375-395. https://doi.org/10.1108/13620430510615300.

Goleman, D. (1998). Working with Emotional Intelligence. New York: Bantam Books.

Guadalupe, M. (2006). Cross cultural adjustment and the expatriate spouse: A Case Study (Unpublished doctoral dissertation). Capella University, Minneapolis.

Gullekson, N. L., \& Tucker, M. L. (2012). An Examination of the Relationship between EI and Intercultural Growth for Students Studying Abroad. Journal of the Academy of Business Education, 13, 62-178.

Hair, J. F., Black, W. C., Babin, J. B., Anderson, R. E., \& Tatham, R. L. (2006). Multivariate Data Analysis (6th ed.). Upper Saddle River, New Jersey, U.S.A: Pearson Prentice-Hall

Harris, P. R., Moran, R. T., \& Moran, S. V. (2004). Managing Cultural Differences: Global Leadership Strategies for the 21st Century. Oxford: Elsevier Heinemann Butterworth.

Haslberger, A. (2008). Expatriate adjustment: a more nuanced view. In M. Dickmann, C. Brewster, \& P. Sparrow (Eds.), International human resource management: a European perspective (2nd ed., pp. 130-149). Abingdon: Routledge.

Hochwarter, W. A., Will, L. A., Treadway, D. C., \& Ferris, G. R. (2006). The Interaction of Social Skill and Organizational Support on Job Performance. Journal of Applied Psychology, 91(1), 482-489. https://doi.org/10.1037/0021-9010.91.2.482

Hofstede, G. H. (1980). Culture Consequences: International Differences in Work-related Values. London: Sage.

Holopainen, J., \& Bjo"rkman, I. (2005). The personal characteristics of the successful Expatriate: A critical review of the literature and an empirical investigation. Personnel Review, 34(1), 37-50. https://doi.org/10.1108/0048348051

HSBC Expat Explorer Survey. (2012). Retrieved January 13, 2013 from http://www.expatexplorer.hsbc.com

Immigration in Malaysia. (2013). Assessment of its Economic Effects, and a Review of the Policy and System. Retrieved June 14, 2014 from psu.um.edu.my/Immigration\%20inMalaysia.

Immigration. (2013). Assessment of its Economic Effects, and a Review of the Policy and System. Retrieved June 14, 2014 from psu.um.edu.my/Immigration\%20in\%20Malaysia.pdf

Jokinen, T. (2005). Global leadership competencies: A review and discussion. Journal of European Industrial Training, 29(3), 199-216. https://doi.org/10.1108/03090590510591085

Jordan, J., \& Cartwright, S. (1998). Selecting expatriate managers: Key traits and competencies. Leadership and Organization Development Journal, 19(2), 89- 96. https://doi.org/10.1108/01437739810208665

Kim, Y. Y. (2001). An Integrative Theory of Communication and Cross-Cultural Adaptation. London: Sage.

Koteswari, V.B., \& Bhattacharya, M. (2007). Managing Expatriate Stress. Delhi Business Review, 8(1), 89-98.

Koveshnikov, A., Wechtler, H., \& Dejoux, C. (2014). Cross-cultural adjustment of expatriates: The role of emotional intelligence and gender. Journal of World Business, 49, 362-371. https://doi.org/10.1016/j.jwb.2013.07.001 
KPMG. (2012). Global Assignment Policies and Practices Survey. Retrieved July 20, 2015 from http://www.kpmg.com/Global/en/IssuesAndInsights/ArticlesPublications

KPMG. (2016). Global Assignment Policies and Practices Survey. Retrieved July 23, 2016 from http://www.kpmg.com/Global/en/IssuesAndInsights/ArticlesPublications

Kraimer, M. L., Wayne, S. J., \& Jaworski, R. A. (2001). Sources of Support and Expatriate Performance: The Mediating Role of Expatriate Adjustment. Personnel Psychology, 54(1), 71-99. https://doi.org/10.1111/j.1744-6570.2001.tb00086

Krejcie, R. V., \& Morgan, D. W. (1970). Determining sample size for research activities. Educational and Psychological Measurement, 30, 607-610. https://doi.org/10.1177/001316447003000308

Lee, H.W. (2005). The factors influencing expatriates. Journal of American Academy of Business, 6(2), 273-278. https://doi.org/10.1080/09585192.2012.725079

Lee, L. Y., \& Sukoco, B. M. (2010). The effects of cultural intelligence on expatriate performance: The moderating effects of international experience. The Int. Journal of Human Resource Management, 21(7), 963-981. https://doi.org/10.1080/09585191003783397

Lee, L.Y., \& Kartika, N. (2014). The Influence of Individual, Family, and Social Capital Factors on Expatriate Adjustment and Performance: The Moderating Effect of Psychology Contract and Organizational Support. Expert System with Applications, 41, 5483-5494. https://doi.org/10.1016/j.eswa.2014.02.030

Leea, L., \& Donohue, R. (2012). The construction and initial validation of a measure of expatriate job performance. The International Journal of Human Resource Management, 23(6), 1197-1215. https://doi.org/10.1080/09585192.2011.638654

Lii, S., \& Wong, S. (2008). The antecedents of overseas adjustment and commitment of expatriates. The International Journal of Human Resource Management, 19(2), 296-313. https://doi.org/10.1080/09585190701799861

Lillis, M. P., \& Tian, R. G. (2009). Cross-cultural communication and emotional intelligence. Inferences from case studies of gender diverse groups. Marketing Intelligence \& Planning, 27(3), 428-438. https://doi.org/10.1108/02634500910955272

Liu, C. H., \& Lee, H. W. (2008). A proposed model of expatriates in multinational corporations. Cross-Cultural Management, 15(2), 176-193. https://doi.org/10.1108/13527600810870615

Locke, E. A. (2005). Why emotional intelligence is an invalid concept. J. Organizational Behavior, 26, 425-431. https://doi.org/10.1002/job.318

Malek, M. A., Jaguli, A. R., \& Palil, M. R. (2012). Enhancing social integration and work performance: the role of expatriates' significant other. Asian Social Science, 9(13), 215-228. https://doi.org/10.5539/ass.v9n13p215

Matsumoto, D., LeRoux, J. A., Bernhard, R., \& Gray, H. (2004). "Unraveling the psychological correlates of intercultural adjustment potential". International Journal of Intercultural Relations, 28, 281-309. https://doi.org/10.1016/j.ijintrel.2004.06.002

Mayer, J. D., \& Salovey, P. (1997). What is emotional intelligence? In P. Salovey, and D. Sluyter (Eds.), Emotional development and emotional intelligence: educational implications. New York: Basic Books.

Mendenhall, M.E, Stevens, M.J., Bird, A. and Oddou, G.R. (2008). Specification of the Content Domain of the Global Competencies Inventory. The Kozai Working paper Series, 1(1), 1-41.

Mercer. (2013). Cultural Awareness Eases Expatriate Assignments. Retrieved July 26, 2014 from $\mathrm{http}: / /$ mthink.mercer.com/cultural-awareness-eases-expatriate-assignments

Mishra, P. S., \& Mohapatra, A. K. (2010). Relevance of Emotional Intelligence for Effective Job Performance: An Empirical Study. Vikalpa, 35(1), 53-61. https://doi.org/10.1177/0256090920100104

Momm, T., Blickle, G., Liu, Y., Wihler, A., Kholin, M., \& Menges, J. I. (2015). It pays to have an eye for emotions: Emotion recognition ability indirectly predicts annual income. Journal of Organization Behaviour, 36, 147-163. https://doi.org/10.1002/job.1975

MSC Malaysia. (2015). Annual Industry Report 2015. Retrieved June 15, 2016 from http://www.mscmalaysia.my

MyStarJob.com. (2014). Expatriate facilitation: An economic imperative. Retrieved August 12, 2017 from 
http://mystarjob.com/articles/story.aspx?file

Neale, S. Spencer-Arnell, L., \& Wilson L. (2009). Emotional Intelligence Coaching: Improving Performance for Leaders, Coaches and the Individual. New Delhi: Kogan Page.

O’Boyle, E. H., Humphrey, R. H., Pollack, J. M., Hawver, T. H., \& Story P. A. (2011). The relation between emotional intelligence and job performance: A meta-analysis. Journal of Organizational Behavior, 32(5), 788-818. https://doi.org/10.1002/job.714

Palthe, J. (2004). The relative importance of antecedents to cross-cultural adjustment: Implications for managing a global workforce. International Journal of Intercultural Relations, 28(1), 37-59. https://doi.org/10.1016/j.ijintrel.2003.12.004

Parke, M. R., Seo, M. G., \& Sherf, E. N. (2015). Regulating and facilitating: The role of emotional intelligence in maintaining and using positive affect for creativity. Journal of Applied Psychology, 100(3), 917-934. https://doi.org/10.1037/a0038452

Peltokorpi, V. (2008). Cross-cultural adjustment of expatriates in Japan. The International Journal of Human Resource Management, 19(9), 1588--1606. https://doi.org/10.1080/09585190802294903

Peltokorpi, V., \& Clausen, L. (2011). Linguistic and cultural barriers to inter-cultural communication in foreign subsidiaries. Asian Business \& Management, 10(4), 509-528. https://doi.org/10.1057/abm.2011.2

Petrides, K. V., \& Furnham, A. (2000). On the dimensional structure of emotional intelligence. Personality and Individual Differences, 29, 313-320. https://doi.org/10.1016/S0191-8869 (99)00195-6

PIKOM. (2012). ICT Strategic Review 2012/13. Retrieved December 12, 2013 from http://www.usearchmedia.com/download

Quebbeman, A., \& Rozell, E. (2002). Emotional intelligence and dispositional affectivity and moderators of workplace aggression. Human Resource Management Review, 12, 125-143. https://doi.org/10.1016/S1053-4822(01)00054-7

Ryan, J. (2000). A Guide to Teaching International Students. Oxford: OCSLD.

Saunders, M., Lewis, P., \& Thornhill, A. (2012). Research methods for business students. Essex: Pearson.

Selmer, J. (2002). Practice Makes Perfect? International Experience and Expatriate Adjustment. Management International Review, 42(1), 71-87.

Sheehan, K. E. (2001). Mail survey response rates: A review. J Compu- Mediated Com., 6(2). https://doi.org/10.1111/j.1083-6101.2001.tb00117

Shi, X., \& Franklin, P. (2014). Business expatriates' cross-cultural adaptation and their job performance. Asia Pacific Journal of Human Resources, 52(2), 193-214. https://doi.org/10.1111/1744-7941.12003

Sinnott, G. C., Madison, G. H., \& Pataki, G. E. (2002). Competencies: Report of the competencies workgroup, workforce and succession planning work groups. New York State Governor's Office of Employee Relations and the Dept. of Civil Service. Retrieved April 8, 2015 from www.cs.ny.gov/successionplanning/workgroups

Stein, S., \& Book, H. (2011). The EQ Edge: Emotional Intelligence and your Success Nississauge:Jossey-Bass.

Steven, P. (2016). Pikom: ICT sector sees drop in salaries, still resilient. The Star, 11 Aug.

Takeuchi, R., Tesluk, P. E., Yun, S., \& Lepak, D. P. (2005). An integrative view of international experience. Academy of Management Journal, 48(1), 85-100. https://doi.org/10.5465/AMJ.2005.15993143

Templer, K.J. (2010). The Personal attributes of expatriate managers, subordinate ethnocentrism, and expatriate success: A host-country perspective. Int. Journal of Human Resource Management, 21(10), 1754-1768. https://doi.org/10.1080/09585192.2010.500493

Tung, R. L. (1982). Selection and training procedures of U.S., European, and Japanese multinationals. California Management Review, 25(1), 57-71.

Viswesvaran, C. (1993). Modeling job performance: Is there a general factor? Unpublished doctoral dissertation, University of Iowa, Iowa City.

Wang, Y., \& Tran, E. (2012). Effects of cross-cultural and language training on expatriates' adjustment and job performance in Vietnam. Asia Pacific Journal of Human Resources, 50(3), 327-350. https://doi.org/10.1111/j.1744-7941.2012.00028 
Witt, L. A., \& Ferris, G. R. (2003). Social skill as moderator of the conscientiousness performance relationship: Convergent results across four studies. Journal of Applied Psychology, 88(5), 809-820. https://doi.org/10.1037/0021-9010.88.5.809

Wong, C. S., Law, K. S., \& Wong, P. M. (2004). Development and validation of a forced choice emotional intelligence measure for Chinese respondents in Hong Kong. Asia Pacific Journal of Management, 21(4), 535-559. https://doi.org/10.1023/B:APJM.000048717.31261

Zeidner, M., Matthews, G., \& Roberts, R. (2004). Emotional intelligence in the workplace: A critical review. Applied Psychology, 33, 371-399. https://doi.org/10.1111/j.1464-0597.2004.00176

Zikmund, W. G., Babin, B. J., Carr, J. C., \& Griffin, M. (2010). Business research methods (8th ed.). Thousand Oaks, CA: Thomson/South-Western.

\section{Copyrights}

Copyright for this article is retained by the author(s), with first publication rights granted to the journal.

This is an open-access article distributed under the terms and conditions of the Creative Commons Attribution license (http://creativecommons.org/licenses/by/4.0/). 